\title{
Oxygen tension modulates the effects of TNF $\alpha$ in compressed chondrocytes
}

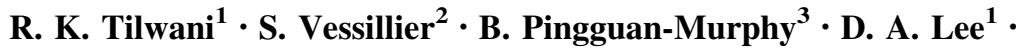 \\ D. L. Bader ${ }^{4}$ T. T. Chowdhury ${ }^{1}$
}

Received: 23 March 2016/Revised: 7 September 2016/Accepted: 13 September 2016/Published online: 22 September 2016

(C) The Author(s) 2016. This article is published with open access at Springerlink.com

\begin{abstract}
Objective and design Oxygen tension and biomechanical signals are factors that regulate inflammatory mechanisms in chondrocytes. We examined whether low oxygen tension influenced the cells response to TNF $\alpha$ and dynamic compression.

Materials and methods Chondrocyte/agarose constructs were treated with varying concentrations of $\mathrm{TNF} \alpha$ $(0.1-100 \mathrm{ng} / \mathrm{ml})$ and cultured at 5 and $21 \%$ oxygen tension for $48 \mathrm{~h}$. In separate experiments, constructs were subjected to dynamic compression $(15 \%)$ and treated with TNF $\alpha(10 \mathrm{ng} / \mathrm{ml})$ and/or L-NIO $(1 \mathrm{mM})$ at 5 and $21 \%$ oxygen tension using an ex vivo bioreactor for $48 \mathrm{~h}$. Markers for catabolic activity $\left(\mathrm{NO}, \mathrm{PGE}_{2}\right)$ and tissue remodelling (GAG, MMPs) were quantified by biochemical assay. ADAMTS-5 and MMP-13 expression were examined by real-time qPCR. 2-way ANOVA and a post hoc Bonferroni-corrected $t$ test were used to analyse data.
\end{abstract}

Responsible Editor: Jason J. McDougall.

\section{T. T. Chowdhury}

t.t.chowdhury@qmul.ac.uk

1 Institute of Bioengineering, School of Engineering and Materials Science, Queen Mary University of London, Mile End Road, London E1 4NS, UK

2 Biotherapeutics Group, National Institute for Biological Standards and Control, South Mimms, Potters Bar, Hertfordshire EN6 3QG, UK

3 Department of Biomedical Engineering, Faculty of Engineering, University of Malaya, Kuala Lumpur 50603, Malaysia

4 Faculty of Health Sciences, Southampton General Hospital, University of Southampton, Southampton SO16 6YD, UK
Results TNFa dose-dependently increased $\mathrm{NO}, \mathrm{PGE}_{2}$ and MMP activity (all $p<0.001$ ) and induced MMP-13 $(p<0.05)$ and ADAMTS-5 gene expression $(\mathrm{p} p<0.01)$ with values greater at $5 \%$ oxygen tension than $21 \%$. The induction of catabolic mediators by $\mathrm{TNF} \alpha$ was reduced by dynamic compression and/or L-NIO (all $p<0.001$ ), with a greater inhibition observed at $5 \%$ than $21 \%$. The stimulation of GAG synthesis by dynamic compression was greater at $21 \%$ than $5 \%$ oxygen tension and this response was reduced with TNF $\alpha$ or reversed with L-NIO.

Conclusions The present findings revealed that $\mathrm{TNF} \alpha$ increased production of $\mathrm{NO}, \mathrm{PGE}_{2}$ and MMP activity at $5 \%$ oxygen tension. The effects induced by TNF $\alpha$ were reduced by dynamic compression and/or the NOS inhibitor, linking both types of stimuli to reparative activities. Future therapeutics should develop oxygen-sensitive antagonists which are directed to interfering with the $\mathrm{TNF} \alpha$-induced pathways.

Keywords TNF- $\alpha$ - Oxygen tension · Chondrocyte . Osteoarthritis - Mechanotransduction

$\begin{array}{ll}\text { Abbreviations } \\ \text { TNFa } & \text { Tumour necrosis factor alpha } \\ \text { NO } & \text { Nitric oxide } \\ \text { MMPs } & \text { Matrix metalloproteinases }\end{array}$

\section{Introduction}

Osteoarthritis (OA) is a progressive joint disease typically characterized by cartilage loss, joint pain and dysfunction. In $\mathrm{OA}$, chondrocytes produce greater levels of pro-inflammatory cytokines such as interleukin $1 \beta$ (IL-1 $\beta$ ) and tumour 
necrosis factor alpha ( $\mathrm{TNF} \alpha$ ) which increase breakdown of the extracellular matrix [1-3]. Whilst IL-1 $\beta$ is the principal cytokine known to drive breakdown of cartilage, TNF $\alpha$ will also contribute to the pro-inflammatory process in chondrocytes [4-7]. There is also strong evidence that biomechanical signals and oxygen tension will additionally cross-talk with the pro-inflammatory process and activate changes that influence tissue remodelling [8-13]. However, little is known about the combined effects of oxygen tension and TNFa on triggering the pro-inflammatory events and how the pathways are regulated by biomechanical signals.

Several in vitro studies have demonstrated that treatment of chondrocytes with TNFa increases production of nitric oxide (NO), prostaglandin $\mathrm{E}_{2}\left(\mathrm{PGE}_{2}\right)$, matrix metalloproteinase (MMP)-1, 3 and 13 and a disintegrin and metalloproteinase with thrombospondin motifs (ADAMTS-5) in human, rabbit, canine or bovine chondrocytes cultured in monolayer, explant or 3D alginate models [5-7, 14-22]. The effects induced by $\mathrm{TNF} \alpha$ were shown to be mediated by the mitogen activated protein kinase (MAPK) family or nuclear factor-kappa B $(\mathrm{NF} \kappa \beta)$, leading to increased proteoglycan depletion and expression of MMP-1, 3 and 13, NO and PGE 2 [23-26]. The $\mathrm{NF \kappa} \beta$ transcription factor was reported to control the expression of several cytokines or MMP enzymes [27, 28] and its regulation by oxygen tension will influence the catabolic effects of the cytokine [29-33]. In addition, oxygen tension was reported to influence the production of $\mathrm{NO}$ and $\mathrm{PGE}_{2}$ in response to biomechanical signals. For example in the chondrocyte/agarose model, low oxygen tension at $5 \%$ enhanced the production of $\mathrm{NO}$ and $\mathrm{PGE}_{2}$ release in constructs cultured with IL-1 $\beta$ when compared to $21 \%$ oxygen tension and this response was abolished by dynamic compression [34]. However, the combined effect of TNF $\alpha$ and biomechanical signals on the production of $\mathrm{NO}$ and $\mathrm{PGE}_{2}$ in chondrocytes at $5 \%$ oxygen tension is not known. The present study therefore examined whether low oxygen tension could influence the response of chondrocytes to $\mathrm{TNF} \alpha$ and dynamic compression by comparing markers for catabolic activity $\left(\mathrm{NO}, \mathrm{PGE}_{2}\right)$ and tissue remodelling (GAG, MMP-13, ADAMTS-5) at 5 and $21 \%$ oxygen tension.

\section{Materials and methods}

\section{Chondrocyte isolation and culture in agarose constructs}

Full depth slices of articular cartilage were isolated from freshly slaughtered cattle aged $<18$ months (Dawn Cardington, Bedfordshire, UK), as previously described [35]. Cartilage tissue was pooled from two joints, diced and incubated on rollers for $1 \mathrm{~h}$ at $37{ }^{\circ} \mathrm{C}$ in Dulbecco's modified Eagle's medium supplemented with $20 \%$ (v/v) foetal calf serum (DMEM $+20 \%$ FCS), $2 \mu \mathrm{M}$ L-glutamine, $5 \mu \mathrm{g} \mathrm{ml}$ penicillin, $5 \mu \mathrm{g} / \mathrm{ml}$ streptomycin, $20 \mathrm{mM}$ Hepes buffer, and $0.85 \mu \mathrm{M}$ L-ascorbic acid +700 unit $/ \mathrm{ml}$ pronase, and for a further $16 \mathrm{~h}$ at $37{ }^{\circ} \mathrm{C}$ in DMEM $+20 \%$ FCS, supplemented with 100 unit/ml collagenase type XI (Sigma Chemical Co., Poole, UK). The cell suspension was washed and viable chondrocytes counted using a haemocytometer and Trypan blue. Cells were resuspended in medium at a cell concentration of $8 \times 10^{6}$ cells $/ \mathrm{ml}$. The cell suspension was added to an equal volume of molten $6 \%$ (w/v) agarose type VII (Sigma Chemical Co., Poole, UK) in Earle's Balanced Salt Solutions (EBSS, Sigma Chemical Co., Poole, UK) to yield a final cell concentration of $4 \times 10^{6}$ cells $/ \mathrm{ml}$ in $3 \%(\mathrm{w} / \mathrm{v})$ agarose. The chondrocyte/agarose suspension was transferred into a sterile stainless steel mould, containing holes $5 \mathrm{~mm}$ in diameter and $5 \mathrm{~mm}$ in height and allowed to gel at $4{ }^{\circ} \mathrm{C}$ for 10 min to yield cylindrical constructs. All constructs were equilibrated in culture in $1 \mathrm{ml}$ DMEM $+20 \% \mathrm{FCS}$ at 5 or $21 \%$ oxygen tension for $72 \mathrm{~h}$.

\section{Effect of oxygen tension and TNF $\alpha$ in chondrocyte/ agarose constructs}

The effect of 5 and $21 \%$ oxygen tension were examined in constructs cultured under free-swelling conditions in a glove-box style workspace integrated within a Biospherix incubator to ensure that the experimental conditions during setup and experimentation were uninterrupted, as previously described [34]. Constructs were cultured with TNFa (Peprotech EC Ltd, London, UK) at concentrations ranging from $0.1,1,10$ and $100 \mathrm{ng} / \mathrm{ml}$ in the presence and absence of $1 \mathrm{mM} \mathrm{L}-\mathrm{N}$-(1-iminoethyl)-ornithine (L-NIO) for up to $48 \mathrm{~h}$. L-NIO inhibits all isoforms of the nitric oxide synthase enzymes (Merck Chemicals, Nottingham, UK).

\section{Application of dynamic compression}

In separate experiments, a novel ex vivo bioreactor (Bose ElectroForce, Gillingham, UK) was used to apply dynamic compression to constructs cultured at 5 or $21 \%$ oxygen tension, as previously described [34]. Constructs were transferred into individual wells of a 24-well culture plate (Costar, High Wycombe, UK) and mounted within the bioreactor system that is integrated within the Biospherix incubator. The medium was supplemented with either 0 or $10 \mathrm{ng} / \mathrm{ml} \mathrm{TNF} \alpha$ in the presence and absence of $1 \mathrm{mM}$ L-NIO and the experimental conditions during setup and culture were uninterrupted. Constructs were subjected to intermittent compression under unconfined conditions, with a profile of 10 min compression followed by a $5 \mathrm{~h}$ 50 min unstrained period for both the 6 and $48 \mathrm{~h}$ culture periods, as previously described [34]. The ex vivo 
conditions were found to be optimal when measuring gene expression and protein synthesis at these time points [34]. The compression regime was applied in a dynamic manner with a strain amplitude of $0-15 \%$ using a sinusoidal waveform at a frequency of $1 \mathrm{~Hz}$ and resulted in duty cycles which ranged from 600 to 4800 cycles for the 6 and $48 \mathrm{~h}$ culture periods, respectively. Control constructs were maintained in an unstrained state in the bioreactor system and cultured for the same time period. At the end of the experiment, the constructs and corresponding media were stored at $-70{ }^{\circ} \mathrm{C}$ prior to analysis.

\section{Biochemical analysis}

$\mathrm{NO}$ and $\mathrm{PGE}_{2}$ production were determined in supernatant by Griess and EIA (GE Healthcare, Buckinghamshire, UK) using well established methods $[34,35]$. Total MMP activity was measured in media samples using a fluorogenic substrate assay. $25 \mu \mathrm{l}$ sample was incubated with $2.5 \mu \mathrm{M}$ amino-phenyl mercuric acetate (APMA) for $1 \mathrm{~h}$ at room temperature to activate latent MMPs. Each sample was subsequently mixed with an equal volume of $10 \mu \mathrm{M}$ Dnp-PChaGCHAK(Nma) fluorogenic MMP substrate, $50 \mu \mathrm{l}$ buffer (500 mM HEPES, $100 \mathrm{mM} \mathrm{CaCl}_{2}, 0.5 \%$ Brij-35, pH 7.0) in a 96-well plate (Enzo Life Sciences, Exeter, UK) and reactions measured at excitation and emission values of 340 and $440 \mathrm{~nm}$, respectively. The change in fluorescence was calculated in the linear region of the kinetic assay for each sample between a period of 5 and $60 \mathrm{~min}$ at $37^{\circ} \mathrm{C}$. GAG synthesis was measured in constructs and media samples by DMMB assay and normalized to DNA values measured using the Hoescht dye 33258 in agarase/papain digests, as described [34, 35].

\section{RNA extraction, cDNA synthesis and real-time quantitative PCR}

RNA was isolated from chondrocytes cultured in agarose as previously described (Qiagen, West Sussex, UK) $[34,36]$. RNA was quantified on the Nanodrop ND-1000 spectrophotometer (LabTech, East Sussex, UK) and reverse transcription was performed using the Enhanced Avian RT First Strand cDNA synthesis kit, oligo(dT) $)_{23}$ primer, and a total of $200 \mathrm{ng}$ of RNA (Sigma Genosys, Cambridge, UK) according to the manufacturer's protocols. Real-time quantitative PCR were performed in $10 \mu \mathrm{l}$ reaction mixtures containing $2.5 \mu \mathrm{l}$ cDNA, $5 \mu \mathrm{l}$ Kapa SYBR $^{\circledR}$ FAST Universal qPCR Master Mix (2X) (Kapa Biosystems, Wilmington, Massachusetts, USA), primer pairs at final concentrations of $0.5 \mu \mathrm{M}$ and nuclease-free PCR-grade water to $10 \mu \mathrm{l}$ (Sigma Genosys, Cambridge, UK). The following specific primer sequences were used: ADAMTS-5 (NM_001166515) Forward: 5'-GCCCTGCCC AGCTAACGGTA-3', Reverse: 5'-CCCCCGGACACACA
CGGAA-3', MMP-13 (NM_174389.2) Forward: 5'-CCC TTGATGCCATAACCAGT- ${ }^{\prime}$, Reverse $5^{\prime}$-GCCCAAAAT TTTCTGCCTCT- $3^{\prime}$ and 18S (NR_036642.1) Forward: $5^{\prime}$ GCAATTATTCCCCATGAACG-3', Reverse: $5^{\prime}$-GGCCT CACTAAACCATCCAA- $3^{\prime}$. Each sample was run in duplicate on the 96-well thermal system of the Mx3000P quantitative PCR instrument (Stratagene, Amsterdam, The Netherlands). Thermocycling conditions comprised an initial polymerase activation step at $95{ }^{\circ} \mathrm{C}$ for $3 \mathrm{~min}$, followed by denaturation of 35 cycles at $95{ }^{\circ} \mathrm{C}$ for $30 \mathrm{~s}$, annealing at $55^{\circ} \mathrm{C}$ for $1 \mathrm{~min}$, and extension at $72{ }^{\circ} \mathrm{C}$ for $1 \mathrm{~min}$. Fluorescence data were collected during the annealing stage of amplification, and data were analysed on the MxPro qPCR software (version 3, Stratagene). Baselines and thresholds were automatically set by the RG-3000 qPCR software and used after manual inspection. The cycle threshold $(\mathrm{Ct})$ value for each duplicate reaction was expressed as the mean value, and the results were exported into Microsoft Excel for further analysis. The data obtained by PCR assay for $18 \mathrm{~S}$ were validated as a reference gene by displaying the $\mathrm{Ct}$ values as box-andwhisker plots, and the distribution examined under the treatment conditions (data not shown). The Ct values for $18 \mathrm{~S}$ remained stable, with no changes detected under all culture conditions, suggesting its suitability as a reference gene. Relative quantifications of ADAMTS-5 and MMP-13 signals were estimated by normalizing each target to the reference gene, $18 \mathrm{~S}$, and to the calibrator sample by a comparative $\mathrm{Ct}$ approach. For each sample, the ratio of target $\Delta \mathrm{Ct}$ and reference $\Delta \mathrm{Ct}$ was calculated, as previously described [36, 37]. Ratios were expressed on a logarithmic scale (arbitrary units).

\section{Statistics}

For free-swelling studies, data represent the mean and SEM values for 6-18 replicates from 3 to 4 separate experiments. For the ex vivo bioreactor experiments, data represent the mean and SEM values of 8-12 replicates from two separate experiments. Statistical analysis was performed by a two-way analysis of variance (ANOVA) and the multiple post hoc Bonferroni-corrected $t$ tests to compare differences between the various treatment groups as indicated in the figure legend. In all cases, a level of $5 \%$ was considered statistically significant $(p<0.05)$.

\section{Results}

\section{Low oxygen tension dose-dependently increased production of catabolic mediators in chondrocytes treated with $\mathrm{TNF} \alpha$}

At 5 and $21 \%$ oxygen tensions, the levels of NO were enhanced by $\mathrm{TNF} \alpha$, with a significant increase at 1,10 and 

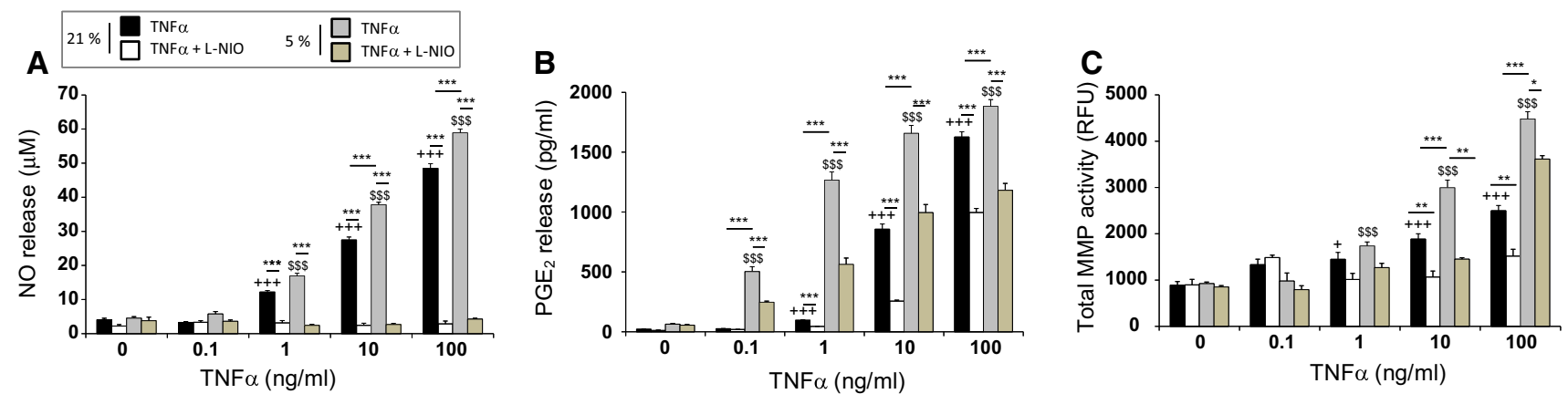

Fig. 1 Effect of 5 and $21 \%$ oxygen tension in chondrocytes treated with varying concentrations of TNF $\alpha$. Chondrocyte/agarose constructs were cultured for $48 \mathrm{~h}$ with varying concentrations of TNF $\alpha$ $(0.1-100 \mathrm{ng} / \mathrm{ml})$ and/or L-NIO $(1 \mathrm{mM})$ and the effects of 5 and $21 \%$ oxygen tension were examined on $\mathrm{NO}$ release (a), $\mathrm{PGE}_{2}$ release (b) and total MMP activity (c). Error bars represent the mean and SEM values for 6-18 replicates from four separate experiments. + or
+++ indicates significant comparisons between untreated and cytokine-treated constructs cultured at $21 \%$ oxygen tension; $\$$ or $\$ \$$ indicates significant comparisons between untreated and cytokine-treated constructs cultured at $5 \%$ oxygen tension; ** or *** indicates significant comparisons between TNF $\alpha$ and $\mathrm{TNF} \alpha+\mathrm{L}-$ $\mathrm{NIO}$

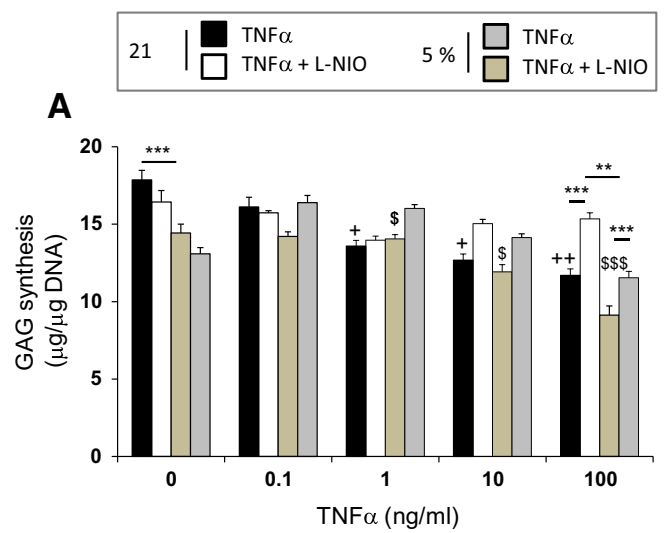

Fig. 2 Dose-dependent effects of TNF $\alpha$ on matrix synthesis and degradation at 5 and $21 \%$ oxygen tension. Chondrocyte/agarose constructs were cultured with varying concentrations of TNF $\alpha$ $(0.1-100 \mathrm{ng} / \mathrm{ml})$ and/or L-NIO $(1 \mathrm{mM})$ for $48 \mathrm{~h}$ and the effects of 5 and $21 \%$ oxygen tension were examined on GAG synthesis (a) and GAG loss (b). Error bars represent the mean and SEM values for

$100 \mathrm{ng} / \mathrm{ml}$, when compared to untreated controls (all $p<0.001$; Fig. 1a). The NOS inhibitor abolished cytokineinduced $\mathrm{NO}$ release with levels returning to basal values at both 5 and $21 \%$ oxygen. At 10 and $100 \mathrm{ng} / \mathrm{ml} \mathrm{TNFa}$, the levels of NO release were greater at $5 \%$ oxygen tension when compared to $21 \%$ (both $p<0.001$ ). TNF $\alpha$ dosedependently increased $\mathrm{PGE}_{2}$ release with values greater at $5 \%$ than $21 \%$ oxygen tension (all $p<0.001$; Fig. 1 b). These effects were partially reversed with the NOS inhibitor (all $p<0.001$ ). TNF $\alpha$ concentrations greater than $1 \mathrm{ng} / \mathrm{ml}$ increased MMP activity in a dose-dependent manner at both oxygen tension when compared to untreated controls (Fig. 1c). Co-incubation with the NOS inhibitor partially reversed this effect in TNF $\alpha$-treated constructs cultured at either 5 or $21 \%$ oxygen. At 10 and

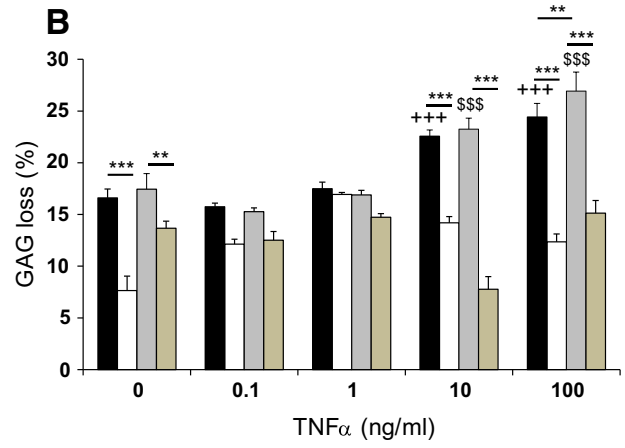

6-18 replicates from four separate experiments. + or +++ indicates significant comparisons between untreated and cytokine treated constructs cultured at $21 \%$ oxygen tension; $\$$ or $\$ \$ \$$ indicates significant comparisons between untreated and cytokine-treated constructs cultured at $5 \%$ oxygen tension; ** or *** indicates significant comparisons between $\mathrm{TNF} \alpha$ and $\mathrm{TNF} \alpha+\mathrm{L}-\mathrm{NIO}$

$100 \mathrm{ng} / \mathrm{ml}$, MMP activity was significantly greater at $5 \%$ oxygen when compared to $21 \%$ (all $p<0.001$ ).

\section{Low oxygen tension dose-dependently influenced matrix synthesis and loss in chondrocytes treated with TNF $\alpha$}

In the absence of the cytokine, GAG synthesis was greater at $21 \%$ oxygen when compared to $5 \%(p<0.001$; Fig. $2 \mathrm{a})$. At low cytokine concentration $(0.1 \mathrm{ng} / \mathrm{ml}), \mathrm{TNF} \alpha$ did not significantly influence GAG synthesis when compared to untreated controls cultured at either 5 or $21 \%$ oxygen (Fig. 2a). At $\mathrm{TNF} \alpha$ concentrations of $1-100 \mathrm{ng} / \mathrm{ml}$, the cytokine downregulated GAG synthesis $(p<0.05)$ but the response was not influenced by the NOS inhibitor, except at 
$100 \mathrm{ng} / \mathrm{ml}$ of TNF $\alpha$. At the highest cytokine concentration $(100 \mathrm{ng} / \mathrm{ml})$, the inhibitory effect on GAG synthesis was greater at $5 \%$ oxygen when compared to $21 \%(p<0.01)$. In the absence of the cytokine, GAG loss was inhibited with L-NIO at both 5 and $21 \%$ oxygen ( $p<0.01$ and $p<0.001$, respectively; Fig. 2b). At TNFa concentrations of $10-100 \mathrm{ng} / \mathrm{ml}$, the cytokine increased GAG loss $(p<0.05)$, and this response was reversed with the NOS inhibitor. At $100 \mathrm{ng} / \mathrm{ml} \mathrm{TNF} \alpha$, the increase in GAG loss was greater at $5 \%$ oxygen when compared to $21 \%(p<0.01)$.

\section{Dynamic compression reduced TNF $\alpha$ induced catabolic effects at 5 and $21 \%$ oxygen}

Figure 3 reveals that in the absence of the cytokine, dynamic compression did not significantly influence NO release at either 5 or $21 \%$ oxygen tension. In unstrained constructs, $\mathrm{TNF} \alpha$ enhanced NO production with a greater effect at $5 \%$ oxygen $(41.6 \mu \mathrm{M})$ when compared to $21 \%$ oxygen $(28.5 \mu \mathrm{M})$, and the response was reduced with dynamic compression (all $p<0.001$; Fig. 3a, b). The magnitude of inhibition was greater at 5 than $21 \%$ oxygen, as indicated in Table 1 , and the inhibitory effect abolished with L-NIO $(p<0.001)$.

In the absence of the cytokine, dynamic compression did not significantly influence $\mathrm{PGE}_{2}$ release at either oxygen tension (Fig. 3c, d). In unstrained constructs, TNF $\alpha$ increased $\mathrm{PGE}_{2}$ release when compared to untreated controls $(p<0.001)$, with values greater at $5 \%$ $(1517.5 \mathrm{pg} / \mathrm{ml})$ than $21 \%(795.1 \mathrm{pg} / \mathrm{ml})$ oxygen tension. Stimulation with either dynamic compression or the NOS inhibitor reduced cytokine-induced $\mathrm{PGE}_{2}$ release (all $p<0.001$ ) with the magnitude of inhibition greater at $5 \%$ than $21 \%$ oxygen tension (Table 1). Co-stimulation with both compression and the NOS inhibitor induced a further reduction in $\mathrm{PGE}_{2}$ release (all $\mathrm{p}<0.001$ ) with the magnitude of inhibition greater at $5 \%$ than $21 \%$ (Table 1 ).

In the absence of the cytokine, dynamic compression did not significantly influence MMP activity at either oxygen tension (Fig. 3e, f). In unstrained constructs, the cytokine increased MMP activity when compared to untreated controls $(p<0.001)$, with values marginally greater at $5 \%$ than $21 \%$ oxygen $(p<0.001)$. Stimulation with dynamic compression or the NOS inhibitor reduced cytokine-induced MMP activity (all $p<0.001$ ) with the magnitude of inhibition greater at $5 \%$ than $21 \%$ oxygen (Table 1$)$. In the presence of $\mathrm{TNF} \alpha$, co-stimulation with compression and L-NIO reduced MMP activity (all $p<0.001$ ) with the magnitude of inhibition broadly similar at both oxygen tensions (Table 1).

\section{Dynamic compression reversed TNF $\alpha$-induced GAG synthesis at 5 and $21 \%$ oxygen}

GAG synthesis was enhanced by dynamic compression when compared to unstrained controls (all $p<0.001$;
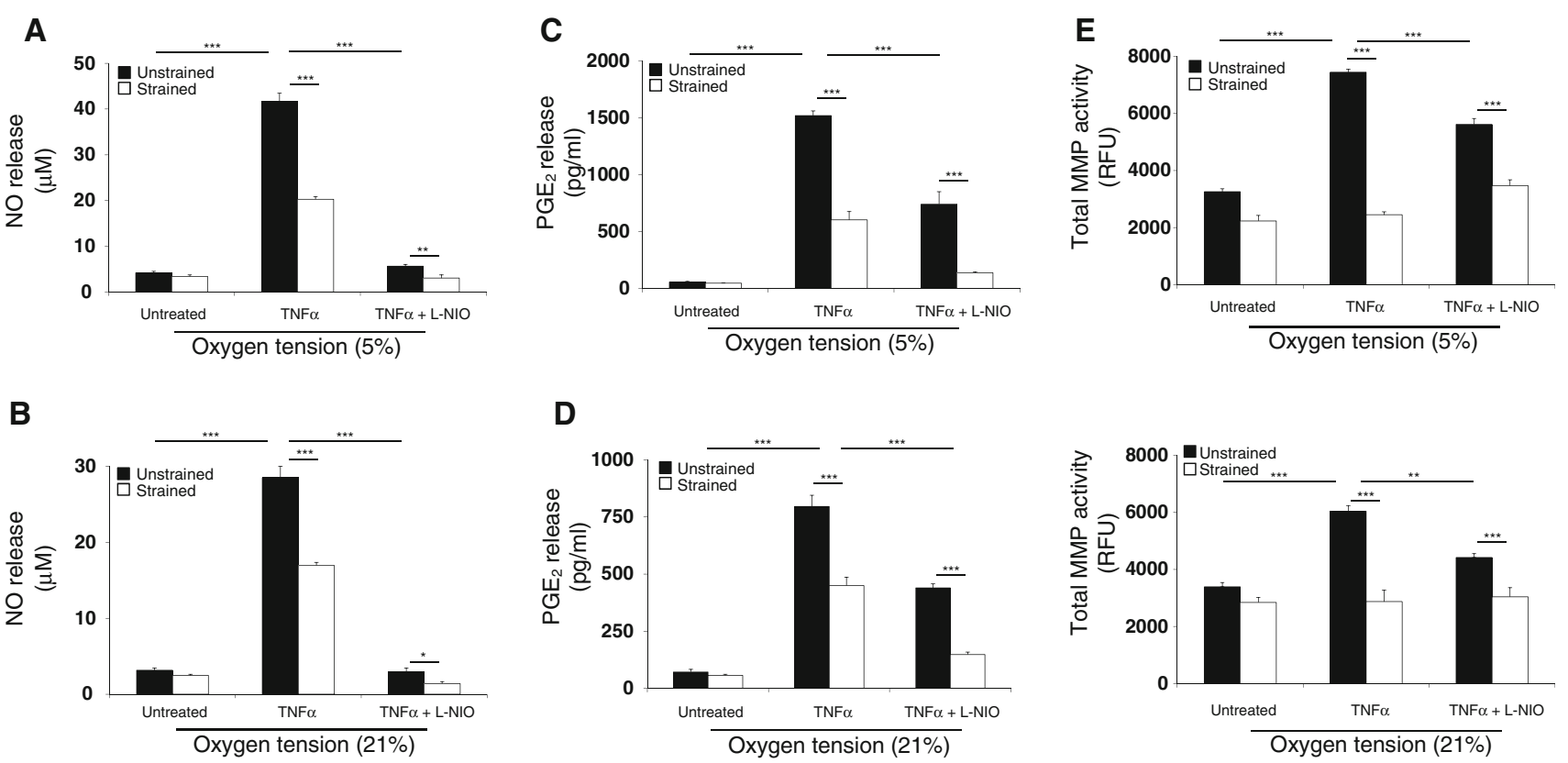

Fig. 3 The effects of TNF $\alpha$ and dynamic compression on the production of catabolic mediators at 5 and $21 \%$ oxygen tension. Chondrocyte/agarose constructs were subjected to dynamic compression $(15 \%, 1 \mathrm{~Hz})$ in the presence or absence of TNFa $(0$ or $10 \mathrm{ng} / \mathrm{ml})$ and/or L-NIO (1 mM) for $48 \mathrm{~h}$ and the effects of 5 and $21 \%$ oxygen were examined on $\mathrm{NO}$ release $(\mathbf{a}, \mathbf{b}), \mathrm{PGE}_{2}$ release $(\mathbf{c}, \mathbf{d})$ and total MMP activity (e, f). Error bars represent the mean and SEM values for $8-12$ replicates from four separate experiments. *, ** or *** indicates significant comparisons between the different treatment conditions. All other comparisons were not significant (not indicated) 
Table 1 The effects of oxygen tension and dynamic compression on catabolic/remodelling activities in chondrocyte/agarose constructs treated with TNF $\alpha$

\begin{tabular}{|c|c|c|c|c|c|c|c|c|}
\hline & \multicolumn{2}{|l|}{ NO release } & \multicolumn{2}{|l|}{$\mathrm{PGE}_{2}$ release } & \multicolumn{2}{|l|}{ MMP activity } & \multicolumn{2}{|l|}{ GAG synthesis } \\
\hline & $21 \%$ & $5 \%$ & $21 \%$ & $5 \%$ & $21 \%$ & $5 \%$ & $21 \%$ & $5 \%$ \\
\hline Untreated & $-20.6( \pm 4.4)$ & $-19.9( \pm 8.3)$ & $-20.8( \pm 4.7)$ & $-17.0( \pm 7.6)$ & $-16.1( \pm 4.9)$ & $-34.4( \pm 7.3)$ & $47.9( \pm 3.1)$ & $32.9( \pm 5.5)$ \\
\hline $\mathrm{TNF} \alpha$ & $-39.9( \pm 2.1)$ & $-50.7( \pm 2.1)$ & $-43.8( \pm 3.3)$ & $-60.3( \pm 4.8)$ & $-43.8( \pm 6.6)$ & $-67.1( \pm 5.1)$ & $106.7( \pm 24.2)$ & $82.3( \pm 7.2)$ \\
\hline $\mathrm{TNF} \alpha+\mathrm{L}-\mathrm{NIO}$ & $-45.3( \pm 8.9)$ & $-47.6( \pm 14.6)$ & $-66.2( \pm 2.6)$ & $-79.9( \pm 2.5)$ & $-66.2( \pm 7.3)$ & $-38.1( \pm 5.9)$ & $64.4( \pm 2.9)$ & $90.9( \pm 5.9)$ \\
\hline
\end{tabular}

Chondrocyte/agarose constructs were subjected to dynamic compression in the presence and absence of TNF $\alpha$ and/or L-NIO at 5 and $21 \%$ oxygen tension for $48 \mathrm{~h}$. Values were expressed as a percentage change from unstrained control samples (\%) where numbers in brackets represent \pm SEM values for $n=8-12$ from four separate experiments

Fig. 4 The effects of TNF $\alpha$ and dynamic compression on GAG synthesis and loss in constructs cultured at 5 and $21 \%$ oxygen. Chondrocyte/agarose constructs were subjected to dynamic compression $(15 \%, 1 \mathrm{~Hz})$ in the presence or absence of $\mathrm{TNF} \alpha(0$ or $10 \mathrm{ng} / \mathrm{ml})$ and/or L-NIO $(1 \mathrm{mM})$ at 5 and $21 \%$ oxygen tension for $48 \mathrm{~h}$ where GAG synthesis $(\mathbf{a}, \mathbf{b})$ and $\mathrm{GAG}$ loss (inset). Error bars represent the mean and SEM values for 8 replicates from two separate experiments. $* * *$ indicates significant comparisons between the different treatment conditions. All other comparisons were not significant (not indicated)

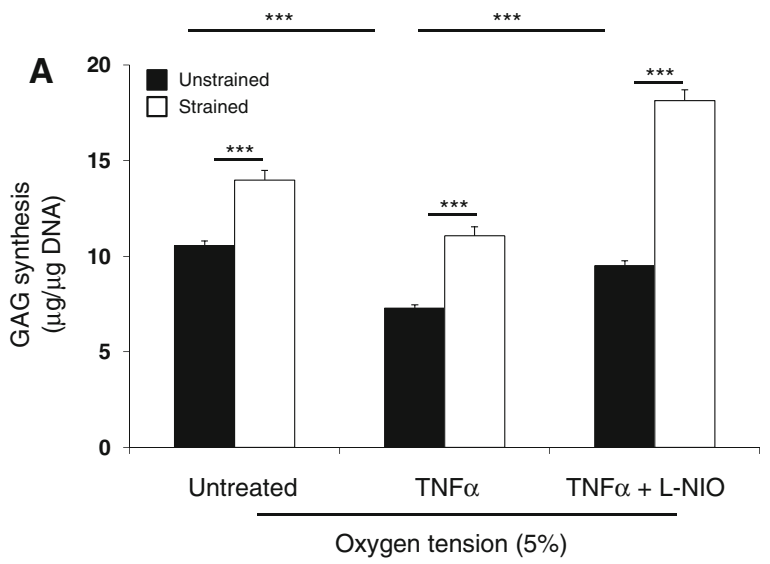

\begin{tabular}{lcc}
\hline GAG loss $(\%)$ & Unstrained & Strained \\
\hline Untreated & 22.6 & 20.6 \\
TNF $\alpha$ & 25.1 & 26.2 \\
TNF $\alpha+$ L-NIO & 29.1 & 22.8 \\
\hline
\end{tabular}

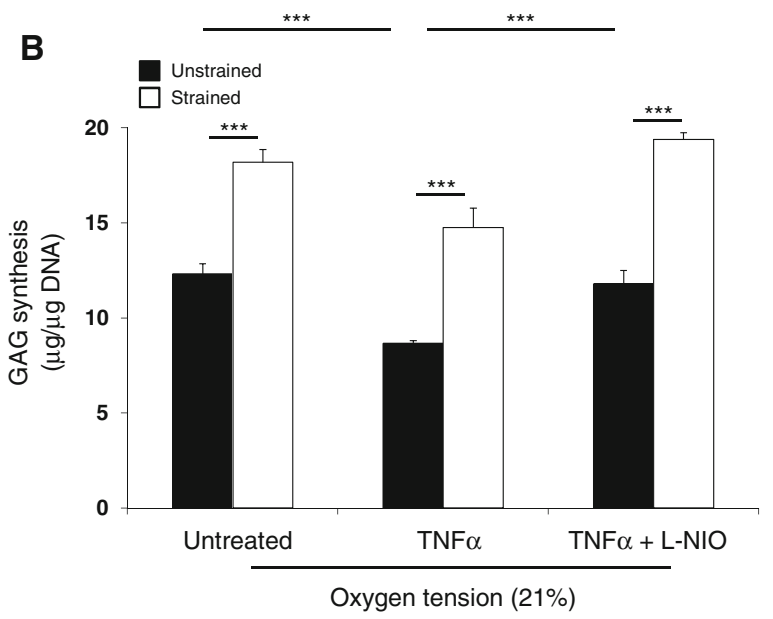

Fig. 4) with a greater magnitude in stimulation for constructs cultured at $21 \%$ oxygen than $5 \%$ (Table 1). At both oxygen tensions, TNF $\alpha$ reduced GAG synthesis (all $p<0.01$; Fig. 4a, b). Dynamic compression increased GAG synthesis in cytokine-treated constructs (both $p<0.001$ ), with the magnitude of stimulation greater at $21 \%$ oxygen than $5 \%$. Co-stimulation with dynamic compression and L-NIO increased GAG synthesis ( $p<0.001$, Fig. 4a, b) with the magnitude of stimulation by dynamic compression greater at $5 \%$ oxygen than $21 \%$ (90.9 vs $64.5 \%$, respectively). GAG loss was not influenced by compression at either oxygen tension (Fig. 4a, b, inset).

Low oxygen tension increased expression of MMP13 and ADAMTS-5 in chondrocytes treated with $\mathrm{TNF} \alpha$ and the response was reduced by dynamic compression

We examined whether oxygen tension influenced gene expression of MMP-13 and ADAMTS-5 in chondrocytes cultured with TNFa and subjected to dynamic 


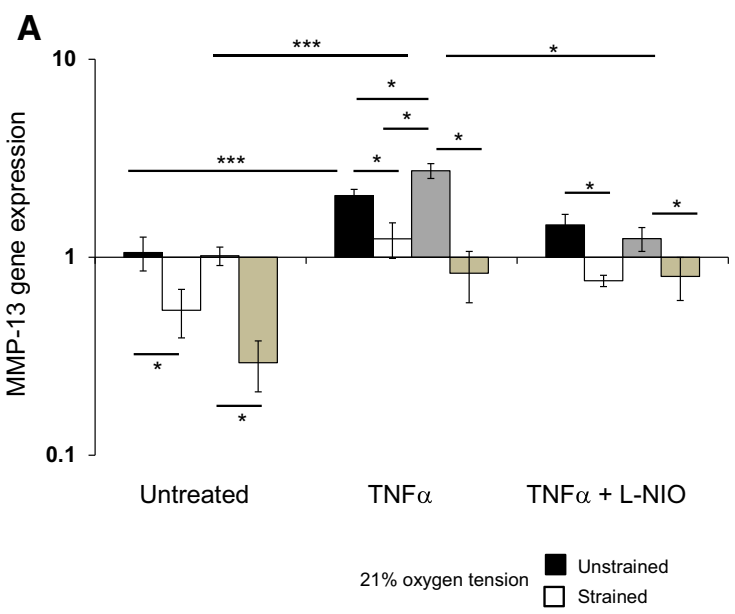

Fig. 5 The effects of TNF $\alpha$ and dynamic compression on MMP-13 and ADAMTS-5 gene expression at 5 and $21 \%$ oxygen. Chondrocyte/agarose constructs were subjected to dynamic compression $(15 \%, 1 \mathrm{~Hz})$ in the presence or absence of TNF $\alpha(0$ or $10 \mathrm{ng} / \mathrm{ml})$ and/ or L-NIO $(1 \mathrm{mM})$ at 5 and $21 \%$ oxygen tension for $48 \mathrm{~h}$ where

compression. At 5 and $21 \%$ oxygen tensions, the presence of TNF $\alpha$ increased gene expression of MMP-13 and ADAMTS-5 when compared to untreated controls (both $p<0.001$; Fig. 5). In unstrained constructs, we observed greater levels of MMP-13 $(p<0.05)$ and ADAMTS-5 $(p<0.01)$ gene expression at $5 \%$ oxygen tension than $21 \%$ oxygen tension. The induction of MMP-13 and ADAMTS-5 gene expression by TNF $\alpha$ at 5 and $21 \%$ oxygen tension were reduced with the NOS inhibitor or abolished by stimulation with dynamic compression.

\section{Discussion}

$\mathrm{TNF} \alpha$ is well known to stimulate production of catabolic mediators such as $\mathrm{NO}$ and $\mathrm{PGE}_{2}$ which inhibit matrix synthesis and induce cartilage degradation [7, 15-22]. The in vitro studies correlate with previous animal studies which showed that selective inhibition of iNOS reduced the symptoms of inflammation and biomechanical abnormalities in osteoarthritic joints [38-40]. However, the overproduction of cytokines in response to oxygen tension and the effect of biomechanical signals on the cell signalling process is less clear. Indeed, the levels of oxygen tension in the diseased joint will have a significant impact on metabolic processes, with the potential to trigger pathways induced by TNF $\alpha$. The interactions between cytokines, oxygen tension and mechanical loading are therefore complex and require further investigation.

In ex vivo studies, we observed dose-dependent increases in $\mathrm{NO}, \mathrm{PGE}_{2}$ and MMPs, that was paralleled with an inhibition of matrix synthesis and loss at the highest cytokine concentration. Reduced oxygen tension at $5 \%$

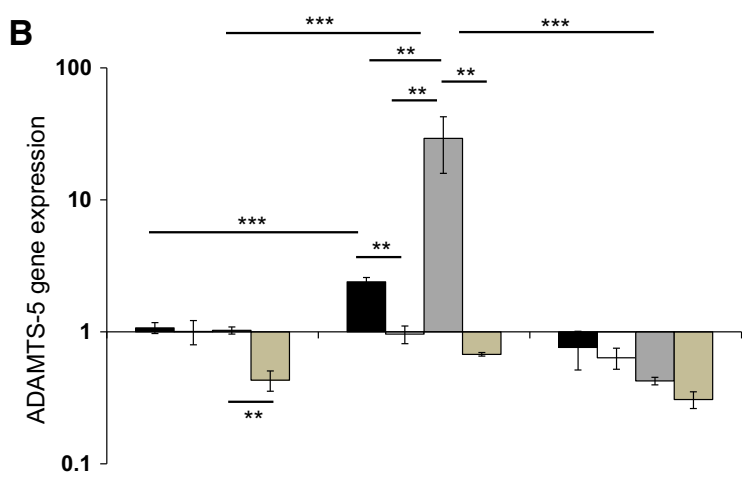

Untreated $\quad$ TNF $\alpha \quad$ TNF $\alpha+$ L-NIO

5\% oxygen tension $\square$ Unstrained

MMP-13 (a) and ADAMT-S5 (b) gene expression. Error bars represent the mean and SEM values for 6 replicates from two separate experiments. $* * *$ indicates significant comparisons between the different treatment conditions. All other comparisons were not significant (not indicated)

was observed to enhance the effects induced by TNF $\alpha$ with greater induction of MMP-13 and ADAMTS-5 gene expression and levels of $\mathrm{NO}, \mathrm{PGE}_{2}$ and MMP activity that also favours the inhibition of matrix synthesis and loss. In a previous study, bovine chondrocytes stimulated with IL-1 $\beta$ in suspension culture exhibited a similar response, with greater levels of $\mathrm{NO}$ and $\mathrm{PGE}_{2}$ production at $5 \%$ when compared to $21 \%$ oxygen tension [30]. The enhanced production of $\mathrm{NO}$ under hypoxic conditions can contribute to the production of reactive oxygen species (ROS) that amplifies the catabolic response [12]. Furthermore, the p55 $\mathrm{TNF} \alpha$ receptor is highly expressed in human chondrocytes from OA cartilage and is particularly susceptible to degradative stimuli [41]. Activation of p55 by TNF $\alpha$ was shown to increase synthesis of $\mathrm{NO}, \mathrm{PGE}_{2}, \mathrm{MMPs}$ and cytokines such as IL-6, IL-8 that degrade collagen type II, IX and XI and inhibit matrix synthesis in a concentrationdependent manner [20-22, 42-44]. However, studies on the effect of low oxygen tension in chondrocytes have resulted in conflicting outcomes. Porcine explants treated with IL- $1 \alpha$ or TNF $\alpha$ increased levels of $\mathrm{NO}$ and $\mathrm{PGE}_{2}$ under normoxic conditions $(21 \%)$ when compared to severe hypoxic conditions (1\%) [31]. In contrast, cytokine-treated chondrocytes induced a reduction in oxidative stress resulting in reduced MMP-9 levels at moderate hypoxia $(6 \%)$ when compared to normoxia $(21 \%)$ and stablization of hypoxia-inducible factor-1 $\alpha$ (HIF-1 $\alpha$ ) expression [32]. Indeed, the regulation of HIF-1 $\alpha$ by oxygen tension may present a potential target for OA therapy, since HIF- $1 \alpha$ over-expression in OA chondrocytes is known to have detrimental effects in cartilage pathophysiology. Furthermore, factors involved in the $\mathrm{NF \kappa} \beta$ and MAPK pathways were shown to mediate production of NO 
induced by the cytokine at $5 \%$ oxygen tension, presenting supplementary oxygen-sensitive mediators as potential therapeutic targets for treating OA [30, 33]. Collectively, these studies emphasize the oxygen-dependency of the proinflammatory induced effects in chondrocytes and suggest that further studies should examine the interplay of the cytokine-induced pathways with oxygen tension.

In ex vivo bioreactor studies, dynamic compression reduced the production of inflammatory mediators in response to TNF $\alpha$, and this response was abolished when dynamic compression was coupled with the NOS inhibitor. We observed differences in the loading-induced response such that the magnitude of inhibition was greater at $5 \%$ oxygen tension than $21 \%$. In addition, the beneficial response was paralleled with anabolic activities as typified by increased matrix synthesis, that was greater at $21 \%$ oxygen tension than $5 \%$. The literature is sparse with respect to the combined effect of TNF $\alpha$ and dynamic compression at low oxygen tensions in chondrocytes. However, the effect of oxygen tension and mechanical stress is well characterized [11, 44, 45]. Matrix synthesis was increased and chondrogenic gene expression was stabilized by long-term mechanical loading at $5 \%$ oxygen tension when compared to $21 \%$ in a chondrocyte/polyurethane model [45]. A similar effect was observed in the alginate model which reported a greater production of GAG synthesis at $5 \%$ oxygen tension compared to $20 \%$ [46]. The differences observed in the present study are due to the type of model system used, e.g. cell type, 2D vs 3D model, primary vs passage cells, free-swelling culture vs mechanical loading, uninterrupted oxygen tension using the biospherix system vs oxygen controlled incubators [47, 48]. Conversely in porcine cartilage explants, mechanical loading enhanced NO production at 5 and $20 \%$ oxygen tension and the response was reduced at $1 \%$ oxygen tension [11, 44]. However, the manner in which cytokine-induced inflammatory pathways are influenced by oxygen tension and biomechanical signals are unclear. Further studies are needed to unravel the distinct pathways induced by oxygen tension, biomechanical signals and TNF $\alpha$. This will help to identify key targets and potential therapies for OA.

In summary, the present study demonstrates that exogenous TNF $\alpha$ combined with low oxygen tension enhanced the production of $\mathrm{NO}, \mathrm{PGE}_{2}$ and MMPs. The effects of TNF $\alpha$ were reduced with biomechanical signals or the presence of the NOS inhibitor in an oxygen-dependent manner, leading to restoration of matrix synthesis. Although selective inhibition of NOS and stimulation with biomechanical signals is chondroprotective, further studies are needed to unravel the distinct pathways induced by oxygen tension, biomechanical signals and TNF $\alpha$. This will help to identify key targets and potential therapies for OA treatments.
Acknowledgments This work was supported by a QMUL Principal EPSRC PhD studentship and project grants by the AO Foundation ( $\mathrm{S}$ 09-83C) and UM High Impact Research Grant (UM.C/HIR/MOHE/ ENG/44) from the Ministry of Higher Education Malaysia.

\section{Compliance with ethical standards}

Conflict of interest The authors declare they have no conflict of interest.

Open Access This article is distributed under the terms of the Creative Commons Attribution 4.0 International License (http:// creativecommons.org/licenses/by/4.0/), which permits unrestricted use, distribution, and reproduction in any medium, provided you give appropriate credit to the original author(s) and the source, provide a link to the Creative Commons license, and indicate if changes were made.

\section{References}

1. Feldmann M, Maini RN. The role of cytokines in the pathogenesis of rheumatoid arthritis. Rheumatology (Oxford). 1999;38(Suppl 2):3-7.

2. Goldring SR, Goldring MB. The role of cytokines in cartilage matrix degeneration in osteoarthritis. Clin Orthop Relat Res. 2004;427 Suppl:S27-36.

3. Houard X, Goldring MB, Berenbaum F. Homeostatic mechanisms in articular cartilage and role of inflammation in osteoarthritis. Curr Rheumatol Rep. 2013;15:375.

4. Kapoor M, Martel-Pelletier J, Lajeunesse D, Pelletier JP, Fahmi $\mathrm{H}$. Role of proinflammatory cytokines in the pathophysiology of osteoarthritis. Nat Rev Rheumatol. 2011;7:33-42.

5. Kobayashi M, Squires GR, Mousa A, Tanzer M, Zukor DJ, Antoniou J, Feige U, Poole AR. Role of interleukin-1 and tumor necrosis factor alpha in matrix degradation of human osteoarthritic cartilage. Arthritis Rheum. 2005;52:128-35.

6. Gilbert SJ, Duance VC, Mason DJ. Tumour necrosis factor alpha up-regulates protein kinase $\mathrm{R}$ (PKR)-activating protein (PACT) and increases phosphorylation of PKR and eukaryotic initiation factor $2-\alpha$ in articular chondrocytes. Biochem Soc Trans. 2002;30:886-9.

7. Goodstone NJ, Hardingham TE. Tumour necrosis factor alpha stimulates nitric oxide production more potently than interleukin$1 \beta$ in porcine articular chondrocytes. Rheumatology (Oxford). 2002;41:883-91.

8. Guilak F. Biomechanical factors in osteoarthritis. Best Pract Res Clin Rheumatol. 2011;25:815-23.

9. Bader DL, Salter DM, Chowdhury TT. Biomechanical influence of cartilage homeostasis in health and disease. Arthritis. 2011;2011:979032.

10. Felson DT. Osteoarthritis as a disease of mechanics. Osteoarthr Cartil. 2013;21:10-5.

11. Fermor B, Christensen SE, Youn I, Cernanec JM, Davies CM, Weinberg JB. Oxygen, nitric oxide and articular cartilage. Eur Cell Mater. 2007;13:56-65.

12. Henrotin Y, Kurz B, Aigner T. Oxygen and reactive oxygen species in cartilage degradation: friends or foes? Osteoarthr Cartil. 2005;13:643-54.

13. Stevens CR, Williams RB, Farrell AJ, Blake DR. Hypoxia and inflammatory synovitis: observations and speculation. Ann Rheum Dis. 1991;50:124-32.

14. Blain EJ. Mechanical regulation of matrix metalloproteinases. Front Biosci. 2007;12:507-27. 
15. Kuroki K, Stoker AM, Cook JL. Effects of proinflammatory cytokines on canine articular chondrocytes in a three-dimensional culture. Am J Vet Res. 2005;66:1187-96.

16. Sabatini M, Thomas M, Deschamps C, Lesur C, Rolland G, de Nanteuil G, Bonnet J. Effects of ceramide on aggrecanase activity in rabbit articular cartilage. Biochem Biophys Res Commun. 2001;283:1105-10.

17. Schuerwegh AJ, Dombrecht EJ, Stevens WJ, Van Offel JF, Bridts $\mathrm{CH}$, De Clerck LS. Influence of pro-inflammatory (IL-1 alpha, IL6, TNF-alpha, IFN-gamma) and anti-inflammatory (IL-4) cytokines on chondrocyte function. Osteoarthr Cartil. 2003;11:681-7.

18. Little CB, Flannery CR, Hughes CE, Mort JS, Roughley PJ, Dent C, Caterson B. Aggrecanase versus matrix metalloproteinases in the catabolism of the interglobular domain of aggrecan in vitro. Biochem J. 1999;344(Pt 1):61-8.

19. Sabatini M, Rolland G, Leonce S, Thomas M, Lesur C, Perez V, de Nanteuil G, Bonnet J. Effects of ceramide on apoptosis, proteoglycan degradation, and matrix metalloproteinase expression in rabbit articular cartilage. Biochem Biophys Res Commun. 2000;267:438-44.

20. Lefebvre V, Peeters-Joris C, Vaes G. Modulation by interleukin 1 and tumor necrosis factor alpha of production of collagenase, tissue inhibitor of metalloproteinases and collagen types in differentiated and dedifferentiated articular chondrocytes. Biochim Biophys Acta. 1990;1052:366-78.

21. Reginato AM, Sanz-Rodriguez C, Diaz A, Dharmavaram RM, Jimenez SA. Transcriptional modulation of cartilage-specific collagen gene expression by interferon gamma and tumour necrosis factor alpha in cultured human chondrocytes. Biochem J. 1993;294(Pt 3):761-9.

22. Campbell IK, Piccoli DS, Roberts MJ, Muirden KD, Hamilton JA. Effects of tumor necrosis factor alpha and beta on resorption of human articular cartilage and production of plasminogen activator by human articular chondrocytes. Arthritis Rheum. 1990;33:542-52.

23. Sondergaard BC, Schultz N, Madsen SH, Bay-Jensen AC, Kassem M, Karsdal MA. MAPKs are essential upstream signaling pathways in proteolytic cartilage degradation-divergence in pathways leading to aggrecanase and MMP-mediated articular cartilage degradation. Osteoarthr Cartil. 2010;18:279-88.

24. Carames B, Lopez-Armada MJ, Cillero-Pastor B, Lires-Dean M, Vaamonde C, Galdo F, Blanco FJ. Differential effects of tumor necrosis factor-alpha and interleukin- $1 \beta$ on cell death in human articular chondrocytes. Osteoarthr Cartil. 2008;16:715-22.

25. Kumar S, Boehm J, Lee JC. p38 MAP kinases: key signalling molecules as therapeutic targets for inflammatory diseases. Nat Rev Drug Discov. 2003;2:717-26.

26. Zwerina J, Hayer S, Redlich K, Bobacz K, Kollias G, Smolen JS, Schett G. Activation of p38 MAPK is a key step in tumor necrosis factor-mediated inflammatory bone destruction. Arthritis Rheum. 2006;54:463-72.

27. Saklatvala J, Rawlinson LM, Marshall CJ, Kracht M. Interleukin 1 and tumour necrosis factor activate the mitogen-activated protein (MAP) kinase kinase in cultured cells. FEBS Lett. 1993;334:189-92.

28. Saklatvala J. Inflammatory signaling in cartilage: MAPK and NFkappaB pathways in chondrocytes and the use of inhibitors for research into pathogenesis and therapy of osteoarthritis. Curr Drug Targets. 2007;8:305-13.

29. Martin G, Andriamanalijaona R, Grassel S, Dreier R, MathyHartert M, Bogdanowicz P, Boumediene K, Henrotin Y, Bruckner P, Pujol JP. Effect of hypoxia and reoxygenation on gene expression and response to interleukin-1 in cultured articular chondrocytes. Arthritis Rheum. 2004;50:3549-60.

30. Mathy-Hartert M, Burton S, Deby-Dupont G, Devel P, Reginster JY, Henrotin Y. Influence of oxygen tension on nitric oxide and prostaglandin E2 synthesis by bovine chondrocytes. Osteoarthr Cartil. 2005;13:74-9.

31. Cernanec J, Guilak F, Weinberg JB, Pisetsky DS, Fermor B. Influence of hypoxia and reoxygenation on cytokine-induced production of proinflammatory mediators in articular cartilage. Arthritis Rheum. 2002;46:968-75.

32. Lawyer TJ, Tucci MA, Benghuzzi HA. Evaluation of chondrocyte growth and function subjected to $21 \%$ and $6 \%$ oxygen levels. Biomed Sci Instrum. 2012;48:246-53.

33. Grimshaw MJ, Mason RM. Bovine articular chondrocyte function in vitro depends upon oxygen tension. Osteoarthr Cartil. 2000;8:386-92.

34. Parker E, Vessillier S, Pingguan-Murphy B, Abas W, Bader DL, Chowdhury TT. Low oxygen tension increased fibronectin fragment induced catabolic activities-response prevented with biomechanical signals. Arthritis Res Ther. 2013;15:R163.

35. Lee DA, Bader DL. Compressive strains at physiological frequencies influence the metabolism of chondrocytes seeded in agarose. J Orthop Res. 1997;15:181-8.

36. Lee DA, Brand J, Salter DM, Akanji OO, Chowdhury TT. Quantification of mRNA using real-time PCR and Western blot analysis of MAPK events in chondrocyte/agarose constructs. Methods Mol Biol. 2011;695:77-97.

37. Pfaffl MW, Horgan GW, Dempfle L. Relative expression software tool (REST) for group wise comparison and statistical analysis of relative expression results in real time PCR. Nucleic Acids Res. 2002;30:e3.

38. Pelletier JP, Lascau-Coman V, Jovanovic D, Fernandes JC, Manning P, Connor JR, Currie MG, Martel-Pelletier J. Selective inhibition of inducible nitric oxide synthase in experimental osteoarthritis is associated with reduction in tissue levels of catabolic factors. J Rheumatol. 1999;26:2002-14.

39. Pelletier JP, Mineau F, Ranger P, Tardif G, Martel-Pelletier J. The increased synthesis of inducible nitric oxide inhibits IL-1ra synthesis by human articular chondrocytes: possible role in osteoarthritic cartilage degradation. Osteoarthr Cartil. 1996;4:77-84.

40. Kammermann JR, Kincaid SA, Rumph PF, Baird DK, Visco DM. Tumor necrosis factor-alpha (TNF-alpha) in canine osteoarthritis: immunolocalization of TNF-alpha, stromelysin and TNF receptors in canine osteoarthritic cartilage. Osteoarthr Cartil. 1996;4:23-34.

41. Westacott CI, Atkins RM, Dieppe PA, Elson CJ. Tumor necrosis factor-alpha receptor expression on chondrocytes isolated from human articular cartilage. J Rheumatol. 1994;21:1710-5.

42. LeGrand A, Fermor B, Fink C, Pisetsky DS, Weinberg JB, Vail TP, Guilak F. Interleukin-1, tumor necrosis factor alpha, and interleukin-17 synergistically up-regulate nitric oxide and prostaglandin E2 production in explants of human osteoarthritic knee menisci. Arthritis Rheum. 2001;44:2078-83.

43. Alaaeddine N, Di Battista JA, Pelletier JP, Kiansa K, Cloutier JM, Martel-Pelletier J. Inhibition of tumor necrosis factor alphainduced prostaglandin E2 production by the antiinflammatory cytokines interleukin-4, interleukin-10, and interleukin-13 in osteoarthritic synovial fibroblasts: distinct targeting in the signaling pathways. Arthritis Rheum. 1999;42:710-8.

44. Fermor B, Weinberg JB, Pisetsky DS, Guilak F. The influence of oxygen tension on the induction of nitric oxide and prostaglandin E2 by mechanical stress in articular cartilage. Osteoarthr Carti. 2005;13:935-41.

45. Wernike E, Li Z, Alini M, Grad S. Effect of reduced oxygen tension and long-term mechanical stimulation on chondrocytepolymer constructs. Cell Tissue Res. 2008;331:473-83.

46. Murphy CL, Polak JM. Control of human articular chondrocyte differentiation by reduced oxygen tension. J Cell Physiol. 2004;199(3):451-9. 
47. Meyer EG, Buckley CT, Thorpe SD, Kelly DJ. Low oxygen tension is a more potent promoter of chondrogenic differentiation than dynamic compression. J Biomech. 2010;43(13):2516-23.

48. Markway BD, Cho H, Anderson DE, Holden P, Ravi V, Little $\mathrm{CB}$, Johnstone B. Reoxygenation enhances tumour necrosis factor alpha-induced degradation of the extracellular matrix produced by chondrogenic cells. Eur Cell Mater. 2016;31:425-39. 